\title{
On the People's Nature of Judicature from the Way of Ma Xiwu's Trial Mode
}

\author{
Bo Zhou \\ School of Public Affairs, University of Science and Technology of China, Hefei, Anhui, China \\ zb199694@mail.ustc.edu.cn
}

\begin{abstract}
As the product of the judicial work under the leadership of the Party during the Chinese revolution, the Ma Xiwu's Trial Mode is a creative contribution of the Chinese Communists to the judicial work, bearing the spiritual core of the red judicial culture of the People's Republic of China, focusing on investigation and research, facilitating the mass litigation and solving disputes on the spot. Under the background of socialism with Chinese characteristics stepping into a new era, people's judicature is the essential feature of socialist judicial system with Chinese characteristics. The core connotation of people's judicature is reflected in Ma Xiwu's judicial stand of people-centered, judicial idea of justice as the core, working principle of insisting on the dialectical unity of people's nature and impartiality of judicature and evaluation standard of reflecting public opinion.
\end{abstract}

Keywords: Ma Xiwu's Trial Mode, New era, People's nature of judicature.

\section{Introduction}

The people's nature of judicature is one of the core elements of Xi Jinping's thought on the rule of law, the concrete embodiment of Xi Jinping's people-centered new development concept in judicial practice, and the essential feature of the socialist judicial system with Chinese characteristics. General Secretary Xi Jinping stressed in the report to the 19th CPC National Congress: "Deepen the comprehensive reform of the judicial system, fully implement the judicial responsibility system, and strive to let the people feel fairness and justice in every judicial case." General Secretary Xi Jinping's scientific judgment, "strive to let the people feel fairness and justice in every judicial case", points out the fundamental goal and task of judicial organs in the new era, is the guide to action of judicial work in the new era. As a case handling mode named after Ma Xiwu, the chief judge of Longdong Branch of the court in shaanxi-Gansu-Ningxia Border region during the War of Resistance against Japanese Aggression in the last century, Ma Xiwu's Trial Mode was not only praised by the authorities, but also recognized by the parties involved in the case and the people. In 2009, Wang Shengjun, then president of the Supreme People's Court, called on courts at all levels across the country to inherit and carry forward the Ma Xiwu's Trial Method in his Work Report of the Supreme People's Court, making the Ma Xiwu trial method a learning object for judicial people.The spirit of Ma Xiwu's Trial Mode accords with the connotation of the people's justice in the new era, and the spiritual tradition of Ma Xiwu's Trial Mode should be inherited and promoted under the new historical conditions.

\section{People-centered Judicial Position}

The people-centered judicial position reflects the original mission of judicial work and is in line with the party's fundamental purpose of serving the people wholeheartedly. Since its establishment, the judicial organs under the leadership of the CPC have taken a people-centered judicial stance. The people-centered judicial position in the new era has been endowed with new connotations. Since the 18th CPC National Congress, General Secretary $\mathrm{Xi}$ Jinping has creatively put forward a series of new concepts, thoughts and strategies for comprehensively governing the rule of law from the strategic perspective of upholding and developing socialism with Chinese characteristics, forming Xi Jinping Thought on the Rule of law.General Secretary Xi Jinping's people-centered concept of the new system has endowed the judiciary with new connotation of the people, that is, to adhere to the principle of judicature for the people[1].

The people-centered judicial position is formed and developed by our Party in the practice of revolution, construction and reform. From the historical development of the party's judicature, our party pays attention to the practice of people's judicature in the period of revolution and construction, summarizes experience through classic cases, forms a system, and guides practice, which has a profound historical tradition and red gene. Known as "a tree growing out of the soil of the masses", the core of Ma Xiwu's trial method is to take the mass line, in-depth investigation at the grass-roots level, the combination of trial and mediation, convenient for the masses to litigate judicial methods, implemented the concept of justice for the people, justice must be impartial, and everything is for the interests of the people[2]. Ma Xiwu's Trial Mode created a judicial democracy in which the masses participated in the trial. For civil cases and even criminal cases, it advocated taking the principle of conciliation first and litigation second under the participation of the people so as to establish the master status of the people to participate in the settlement of conflicts and disputes in institutional construction. At the same time, it has established the principle of equality in democracy and the legal system, stressed that revolutionary laws should reflect the unity of class nature and people's nature, determined the principle of equality before the law, and established the principle that Communist Party members and leading cadres should strictly govern the Party, the army, govern the Party and the army in accordance with the law. The handling methods or ideas of some classic case were deeply supported by the people, and condensed into the legal provisions and basic system of people's justice under the leadership of the Party, and eventually become the core content of the people's judicial system. Therefore, at present, we should adhere to the judicial work for the people, improve the style of judicial 
work, through enthusiastic service, effectively solve the problem of people's difficulty in filing lawsuits, especially to increase the legal aid to the needy people to safeguard their legitimate rights and interests. Judicial workers should keep close contact with the masses, standardize the judicial behavior and increase judicial openness, respond to the people's concerns and expectations of judicial fairness and openness, and reflect the initial aspiration and mission of judicial work[3].

\section{Justice-centered Judicial Philosophy}

Fairness is the essence of the law, fairness and justice is the value pursuit of socialism with Chinese characteristics, fairness in administration of justice and safeguarding social fairness and justice are the essential requirements of the socialist judicial system with Chinese characteristics, and the concrete embodiment of the people's nature of the judiciary. General Secretary Xi Jinping has pointed out, we must ensure and promote social fairness and justice to comprehensively govern the country according to law. Fairness and justice is a very noble value our Party pursues. Serving the people wholeheartedly determines that we must pursue fairness and justice, protect the people's rights and interests, and uphold justice. Seeking truth from facts and proceeding from reality are the essential characteristics of Ma Xiwu's Trial Mode. Paying attention to investigation and research is the basic principle of Marxist materialist dialectics as well as the fine tradition of our Party. Under certain historical conditions, ma Xiwu took investigation and research as the main way for judges to find out the facts, which made up for the deficiency of sitting in court and finally won the people's affirmation and praise. On March 13, 1944, Liberation Daily published "Su Fayun killing three brothers for profit", "Wang Zhikuan land dispute cases", these reports reflected that Ma Xiwu's Trial Mode insists all embark from the reality, it stands for being objective, comprehensive and in-depth in investigation and study, treating evidence meticulously, treating uncertain points with rigorous analysis and making full exhaustive survey about facts. Finally, it becomes a banner of the judicial work in the anti-Japanese base area.

In the new era, the rule of law, as a basic way of governing the country, has been placed in an unprecedented prominent position, and the people have put forward higher requirements for judicial credibility, which is a major change in social progress. Judicial work must change with the change, actively respond to the concerns of the people, to speed up the pace of reform of the judicial system, perfect the mechanism of the judicial system, fully solve the profound problems affecting justice and judicial capacity, improve the quality of justice, judicial efficiency and judicial credibility, in order to advance the process of construction of law-based country, law-based government and law-based society.

\section{The Working Principle of the Dialectical Unity of the People and Justice of Judicature}

The people's nature and justice of judicature are the relations of dialectical unity. The people's nature of judicature shows that the construction and work of judicature in Our country has a profound mass foundation. Judicature must serve the people, it depends on the people and benefit to the people. The people's nature of judicature is the fundamental position of judicature, and impartiality is its basic requirement. Through the people's nature of judicature, the fairness of judicature is constantly promoted, and the promotion of impartiality provides the basic guarantee for winning the credibility and authority of judicature. The dialectical unity of the people and justice of the judiciary fully embodies the core values and basic characteristics of the socialist judicial system, which is the most distinctive progress and superiority of the socialist judicial system with Chinese characteristics compared with the western judicial system.

Ma Xiwu's Trial Mode is widely praised, largely due to the distinctive characteristics concluding solving disputes on the spot, solving problems in various approaches, simplifying the judicial procedures and providing conveniences for litigation. In April 1939, the Policy Program of the Shaanxi-Gansu-Ningxia Border Area during the War of Resistance against Japanese Aggression stipulated that a judicial system for the convenience of the people should be established. On 10 May 1941, the High Court of the border region directed that the litigants could not be refused with or without a complaint. Under the specific background that the enactment law could not meet the needs of adjudication, Ma Xiwu carried out the provisions of convenience seriously and carried them forward further in practice. When he was on trial circuit, he accepted cases at any time and anywhere, understood the facts of the case, investigated and tried on the spot, did not blame the masses, never assumed the official AIRS as a judge and always be clear that he is a "social public servant" to facilitate the masses for the purpose. Besides, the goal of Ma Xiwu's Trial Mode is the end the disputes with substantive settlement. Paying attention to the combination of trial and mediation, the combination of adjustment and judgment, and figuring out clear results is the magic weapon for Ma Xiwu's Trial Mode to settle disputes and lawsuits. Ma Xiwu was not simply making judgment at work, but adopted flexible and diverse methods according to the characteristics and psychological state of the parties, the strategy is focusing on reversing the opposing emotions of the parties, understanding the law and human feelings, explaining the interests of the parties, so that the parties are convinced, and finally resolved the conflict from the source, rather than a simple verdict. The handling of the "sealing marriage case" punished the illegal acts, struck down the feudal arranged marriage, protected the normal marriage relationship, educated the cadres and the masses, and won the support and praise of the masses[4].

Therefore, the popularity of judicature needs to be realized through the justice of judicature. If the people cannot maintain their legal rights through judicial procedures, there will be no credibility in justice and the people will not believe in justice. Only a fair judiciary can truly defend justice as the last line of defense for social fairness and justice, win the credibility and authority of the judiciary, and win the trust of the people. At the same time, the judicature must adhere to the people-centered work, adhere to the position of the people, serve the people, meet their judicial needs, and respond to their judicial expectations[5]. 


\section{The Evaluation Criteria Related to the Actual Feelings of the People}

Judicial work should be aimed at solving the practical problems of the people and meeting their urgent needs. The judicial system of our country reflects the fundamental will of the vast majority of the people, and the realization, maintenance and development of the fundamental interests of the vast majority of the people are the fundamental starting point and foothold of our judicial work[6]. The people are the makers of history and the real heroes. Adhering to view the people as the center to promote judicial work is not only the inevitable requirement and the profound embodiment of the party's fundamental purpose, but also the spiritual essence and important principle of China's Constitution. The people are the true masters of history, the creators of social material and spiritual wealth and the decisive force for social change. Serving the people wholeheartedly is the fundamental purpose of the CPC, and all the Party's endeavors are for the benefit of the overwhelming majority of the people. This is the direction and principle of our work. Ma Xiwu was able to end his cases without disputes because he had implemented the Party's mass line, relied on the masses and listened to their opinions. When Ma Xiwu emphasized the mass line and respected the opinions of the masses, he did not blindly accept the opinions and demands of the masses unconditionally, but based on the conformity with policies, laws and make sure the evidences are objective and true. He said "the masses are not experts in law and are not skilled in investigative techniques, and their opinions may be temporarily confused by the false impression created by the perpetrator." Only after the facts of the case were found out and the right and wrong were put before the masses did local cadres and the masses be mobilized to argue the case with the party concerned. It should be noted that, under the historical conditions at that time, relying on the informed masses, combining the principles of policies and laws with specific circumstances, and putting forward feasible measures for closing cases was the most vivid practice of the Party's mass line[7].

It is the enlightening guidance left by Ma Xiwu's Trial Mode to the judicial work to consult the people about politics, needs and plans, and extensively listen to the people's opinions. Therefore, today, deepening the reform of the judicial system, to widely listen to the people's opinions, in-depth understanding of the actual situation of front-line justice, the people's satisfaction with the solution of the problem as the standard to judge the effectiveness of the reform is the inevitable follow of the realization of the people's justice.

\section{References}

[1] Cui Yadong, on the popular nature of judicature. Oriental Law, 2021(05): 4-20.

[2] Xiao Zhoulu and Ma Jingping, Ma Xiwu trial mode new exploration. Jurist, 2012(06): 1-15+174.

[3] Fang Le, the practice of people-centered judicial concept and its logical implication. Law Science (Journal of Northwest University of Political Science and Law), 2021. 39(04): 3-13.
[4] Revitalize the Party and inherit the essence of Ma Xiwu's trial method, in People's Court Newspaper 2021. Page 1.

[5] Feng Jing, How to Make the Masses Feel judicial Justice, in People's Court Journal 2021. Page 2.

[6] Ren Lixuan, The fundamental starting point and foothold of building and strengthening the Party, in People's Daily 2021. Page 4.

[7] He Xiaorong, The inner spirit of "Ma Xiwu Trial Mode" and its Value of The Times. Application of Law, 2021(06): 3-7. 